This is an electronic reprint of the original article. This reprint may differ from the original in pagination and typographic detail.

\author{
Author(s): Lechner, Clemens M.; Pavlova, Maria K.; Sortheix, Florencia; Silbereisen, Rainer K.; \\ Salmela-Aro, Katariina
}

Title: $\quad$ Unpacking the link between family socioeconomic status and civic engagement during the transition to adulthood : Do work values play a role?

Year: $\quad 2018$

Version:

Please cite the original version:

Lechner, C. M., Pavlova, M. K., Sortheix, F., Silbereisen, R. K., \& Salmela-Aro, K. (2018). Unpacking the link between family socioeconomic status and civic engagement during the transition to adulthood : Do work values play a role?. Applied Developmental Science, 22(4), 270-283.

https://doi.org/10.1080/10888691.2017.1291352

All material supplied via JYX is protected by copyright and other intellectual property rights, and duplication or sale of all or part of any of the repository collections is not permitted, except that material may be duplicated by you for your research use or educational purposes in electronic or print form. You must obtain permission for any other use. Electronic or print copies may not be offered, whether for sale or otherwise to anyone who is not an authorised user. 


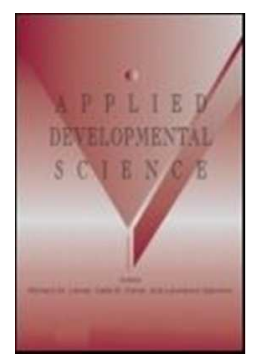

\section{Unpacking the Link between Family Socioeconomic Status and Civic Engagement during the Transition to Adulthood: Do Work Values Play a Role?}

\begin{tabular}{|r|l|}
\hline Journal: & Applied Developmental Science \\
\hline Manuscript ID & Draft \\
\hline Manuscript Type: & Empirical Article \\
\hline Keywords: & $\begin{array}{l}\text { civic engagement, work values, parental occupational status, transition to } \\
\text { adulthood, family socioeconomic status }\end{array}$ \\
\hline Abstract: & $\begin{array}{l}\text { We investigated whether the link between family-of-origin socioeconomic } \\
\text { status (SES) and civic engagement in young adulthood is mediated by } \\
\text { youth's work values, i.e., the desired characteristics of their current or } \\
\text { future jobs. We used data from a Finnish study: 2004 (age 16-18, NT1 }= \\
1,301) ; 2011 \text { (age 23-25, N T2 = 1,096); and 2014 (age 25-27, NT3 } \\
\text { 1,138). A lower family SES in 2004 was negatively related to youth's civic } \\
\text { engagement in 2014. Lower family SES predicted the importance that } \\
\text { youth attached to extrinsic job rewards (e.g., good pay) in 2011, but not } \\
\text { the importance of intrinsic job rewards (e.g., learning opportunities). } \\
\text { Extrinsic work values, in turn, predicted lower civic engagement in 2014, } \\
\text { above and beyond sociodemographic and personality characteristics. } \\
\text { Conversely, intrinsic work values predicted higher civic engagement. Thus, } \\
\text { extrinsic, but not intrinsic, work values partly mediated the link between } \\
\text { SES and youth civic engagement. }\end{array}$ \\
\hline
\end{tabular}

\section{SCHOLARONE ${ }^{\text {M }}$ \\ Manuscripts}


Unpacking the Link between Family Socioeconomic Status and Civic Engagement during the Transition to Adulthood: Do Work Values Play a Role? 


\begin{abstract}
We investigated whether the link between family-of-origin socioeconomic status (SES) and civic engagement in young adulthood is mediated by youth's work values, i.e., the desired characteristics of their current or future jobs. We used data from a Finnish study: 2004 (age 16$\left.18, N_{\mathrm{T} 1}=1,301\right) ; 2011\left(\right.$ age $\left.23-25, N_{\mathrm{T} 2}=1,096\right)$; and 2014 (age 25-27, $\left.N_{\mathrm{T} 3}=1,138\right)$. A lower family SES in 2004 was negatively related to youth's civic engagement in 2014. Lower family SES predicted the importance that youth attached to extrinsic job rewards (e.g., good pay) in 2011, but not the importance of intrinsic job rewards (e.g., learning opportunities). Extrinsic work values, in turn, predicted lower civic engagement in 2014, above and beyond sociodemographic and personality characteristics. Conversely, intrinsic work values predicted higher civic engagement. Thus, extrinsic, but not intrinsic, work values partly mediated the link between SES and youth civic engagement.
\end{abstract}

Keywords: civic engagement; family socioeconomic status; work values; parental occupational status; transition to adulthood. 
Unpacking the Link between Family Socioeconomic Status and Civic Engagement during the Transition to Adulthood: Do Work Values Play a Role?

For a democracy to function well, citizens should care about social and political issues, know how to express and defend their political interests in a constructive way, and be prepared to support disadvantaged groups. An important way of achieving this is civic engagement: individual and collective action designed to identify and address issues of public concern (APA, 2015). Civic knowledge, skills, and motivations that are requisite for such action are largely formed in youth and early adulthood (Flanagan \& Levine, 2010). Through civic engagement, young people not only contribute to the common good, but also benefit themselves, e.g., by making social connections, acquiring knowledge and skills, and even finding work opportunities (Ruiter \& De Graaf, 2009; Wilson \& Musick, 2003).

Because of these benefits, persistent social inequalities in the rates of civic engagement raise concerns among both researchers and policy-makers (Flanagan \& Levine, 2010; Levinson, 2010; Verba et al., 1995). Research has consistently linked lower SES to lower rates of volunteering, charitable giving, and political engagement in youth (Brown \& Lichter, 2007; Janoski \& Wilson, 1995; Verba et al., 1995). However, little is currently known about the psychological pathways that could explain this association. In the present study, we propose that one such pathway may be found in the values individuals place on different aspects of paid work, a life domain that becomes central during the transition to adulthood.

We argue that youth's work values (i.e., the importance that they place on different characteristics of their current or future jobs; Johnson \& Mortimer, 2011; Taris \& Feij, 2001) may influence their participation in other life domains, including civic life. In particular, we draw on the selection-optimization-compensation model (SOC; Baltes, 1997), which posits that 
individuals possess limited resources that they have to invest selectively to achieve desired outcomes. Consequently, it pays off to pursue similar and mutually facilitating life goals. Indeed, SOC-based research has found that when individuals perceive conflict between life goals, they exhibit lower goal engagement and lower subjective well-being (Riediger \& Freund, 2004; Wiese \& Salmela-Aro, 2008). Intergoal facilitation occurs when progressing towards one goal simultaneously helps in pursuing another; whereas, intergoal conflict occurs when the pursuit of one goal interferes with the pursuit of another (Riediger \& Freund, 2004). Depending on the adopted perspective, civic engagement can be viewed as promoting one's career success, or as irrelevant or even disadvantageous to it. Youth who value intrinsic job rewards (i.e., interesting jobs, learning, and having variety; Johnson \& Mortimer, 2011; Taris \& Feij, 2001) may tend to perceive civic engagement as compatible with their career goals, because civic engagement constitutes a self-directed activity that typically provides ample learning opportunities (Wilson, 2012). In contrast, those who value extrinsic job rewards (i.e., job security and material rewards) may tend to perceive the two domains as mutually interfering, because civic engagement does not bring immediate material rewards and can be time-consuming (Wilson, 2012).

As youth from lower-SES backgrounds tend to prioritize extrinsic job rewards (Johnson \& Mortimer, 2011), work values may be considered as a candidate mechanism that explains the link between family SES and civic engagement. We examined this idea using data from a 10-year longitudinal study of Finnish youth, investigating whether young adults' work values mediate the effect of family SES assessed in adolescence on civic engagement in young adulthood. We tested the effects of work values against competing explanatory variables, including young adults' own SES, personality traits, and autonomous motivation. Below, we briefly review the extant literature on each of the paths implicated by our mediational model and explain our study design. 


\section{Family SES and Offspring's Civic Engagement}

The most prominent accounts of socioeconomic gaps in youth civic engagement stem from sociological research, which has identified status transmission and role modeling as possible mechanisms (Janoski \& Wilson, 1995; Mustillo, Wilson, \& Lynch, 2004; Verba et al., 1995). Status transmission implies that children of higher-SES parents grow up to have a higher SES themselves. A higher SES, in turn, fosters civic engagement, presumably because better-off persons are more aware of civic and political issues, possess more "civic skills" (e.g., public speaking), are more socially integrated, and are more likely to be recruited by civic organizations (Verba et al., 1995; Wilson, 2012). Role modeling means that higher-SES parents are themselves more likely to be civically engaged, setting an example for their children (Janoski \& Wilson, 1995; Mustillo et al., 2004). However, to reduce SES disparities in youth civic engagement, it is critical for researchers to study mediators other than SES and parental civic engagement, because these are as difficult to target in interventions.

Psychological research has sought to explain the family SES-youth civic engagement link through such mediators as parent-child connectedness (Carlo, Padilla-Walker, \& Day, 2011) and adolescent self-esteem and cognitive ability (Brown \& Lichter, 2007), all of which may be undermined by family socioeconomic disadvantage. However, such mediators reflect overall positive functioning rather than age-specific developmental tasks, and they have little conceptual relation to civic engagement. Probably for these reasons, the evidence for mediation via psychological variables has often been very limited (e.g., Brown \& Lichter, 2007). Thus, a need exists to elucidate other psychological mechanisms that might explain the lower rates of civic engagement among lower-SES offspring. We propose that one such mechanism may be found in young adults' work values. 


\section{Family SES and Work Values}

Recent studies following U.S. and Finnish young adults have tied a lower family SES to more extrinsic work orientations (Johnson \& Mortimer, 2011; Sortheix, Chow, \& Salmela-Aro, 2015). In contrast, some scholars have argued that a higher family SES may foster valuing intrinsic job rewards (Kohn \& Schooler, 1969). However, recent studies have failed to find this link, at least in Western samples (Johnson \& Mortimer, 2011; Sortheix et al., 2015).

The link between family SES and youth work values has been explained by two mechanisms: socialization and compensation. Socialization implies that parents' own work experiences shape their work values, which they directly convey to their children. As Kohn and Schooler (1969) remarked, "The conditions of occupational life at lower social class levels limit men's view of the job primarily to extrinsic benefits it provides, foster[ing] a narrowly circumscribed conception of self and society" (p. 677). Compensation means that youth raised in relatively disadvantaged contexts come to prioritize material aspects of work (e.g., job security, salary) to compensate for experiences of material insecurity. In contrast, youth from more privileged families may take extrinsic job rewards for granted and can afford focusing on higherlevel needs, e.g., personal growth (e.g., Johnson \& Mortimer, 2011). Thus, family SES influences what kinds of rewards youth will strive to attain through paid work. These work values, in turn, may affect the selection of goals and behaviors in other life domains, including civic engagement, as we will argue next.

\section{Consequences of Work Values for Work and Non-Work Outcomes}

Work values have well-known consequences for work-related outcomes. Higher intrinsic work values predict better quality jobs and actually obtained intrinsic job rewards (Johnson \& Monserud, 2012; Johnson \& Mortimer, 2011). Higher extrinsic work values, by contrast, are 
associated with a lower level of well-being at work, heightened work-family conflict, and working longer hours (which also implies higher earnings, Johnson \& Monserud, 2012; Vansteenkiste et al., 2007). Although this evidence suggests that valuing extrinsic job rewards may result in focusing on work at the expense of other life domains, the cross-domain effects of work values have hardly been investigated. Most importantly, no study appears to have used work values to predict civic engagement, even though evidence exists that participating in volunteering activities and intrinsic work values are positively interrelated in U.S. adolescents (Johnson, Beebe, Mortimer, \& Snyder, 1998).

It seems highly probable that such cross-domain effects exist, especially in young adulthood. During this life stage, work emerges as a central life domain affecting other domains, including civic engagement (Pavlova \& Silbereisen, 2014). For young people, engaging in paid work is a novel and sometimes overwhelming task. For this reason, working full-time may deter some of them from engaging civically (Oesterle, Johnson, \& Mortimer, 2004). However, paid work can also facilitate civic engagement, because employed individuals are more accessible than the unemployed or homemakers and may possess skills that are attractive to potential recruiters (Wilson, 2012). Moreover, young workers may become civically engaged in the hopes of improving their labor market opportunities through the acquisition of skills and social contacts that are particularly relevant at early career stages (Pavlova \& Silbereisen, 2014). Indeed, the functional approach to volunteers' motivations has long acknowledged that civic activities are driven by a mixture of motives beyond pure altruism, including career-related ones (Clary \& Snyder, 1999).

Given these important linkages between work and civic engagement, we expect individual differences in work values to affect civic engagement. Valuing extrinsic versus 
intrinsic job rewards reflects distinct motivations to pursue work-related goals, which may be in conflict or in harmony with civic goals. Building on the SOC model (Baltes, 1997), we argue that individuals' work motivation may have spillover effects to other life domains. Even though individuals may become civically engaged partly for pragmatic reasons (i.e., to find a job and to promote their careers; Clary \& Snyder, 1999; Pavlova \& Silbereisen, 2014; Wilson \& Musick, 2003), this course of action is more likely in those who value intrinsic, rather than extrinsic, job rewards. If youth place a high value on intrinsic job rewards (i.e., opportunities for initiative, self-direction, and realization of their interests and skills), civic engagement may indeed appeal to them as a meaningful, self-directed activity that provides learning experiences to be applied in their future jobs. In other words, valuing intrinsic job rewards may lead to a mutual facilitation (Riediger \& Freund, 2004) of career goals and civic goals. In contrast, if youth place much emphasis on extrinsic job rewards (i.e., salary, status, and job security), they may find civic engagement to be in conflict with their goals at work. This is because, although potentially useful career-wise in the long-run (Ruiter \& De Graaf, 2009; Wilson \& Musick, 2003), civic engagement provides neither immediate material rewards nor job security.

\section{The Present Study}

The goals of this study were to investigate: (a) whether young individuals' work values predict their civic engagement; (b) whether work values mediate the relationship between family SES and young adults' civic engagement; and (c) whether these effects are robust to the presence of rival explanatory variables. We expected a lower family SES in adolescence to predict lower civic engagement (Hypothesis 1), and a higher importance of extrinsic and a lower importance of intrinsic job rewards (Hypotheses $2 \mathrm{a}$ and $2 \mathrm{~b}$, respectively) in young adulthood. Furthermore, we anticipated a higher importance of extrinsic job rewards to predict lower civic engagement 
(Hypothesis 3a) and a higher importance of intrinsic job rewards to predict higher civic engagement (Hypothesis 3b). Finally, we hypothesized that work values would mediate the effect of family SES on offspring's civic engagement (Hypothesis 4).

To test these propositions, we utilized data from the Finnish Educational Transitions (FinEdu) studies, which followed Finnish secondary school students through their transitions into further education and employment. We operationalized family SES via its key indicator, parental occupational status (Lien, Friestad, \& Klepp, 2001). Drawing on the popular distinction between giving time and giving money (Verba et al., 1995), we differentiated between three types of civic engagement: financial engagement (i.e., monetary donations and politically motivated consumption), political activism (i.e., signing a petition and taking part in political events), and volunteering (i.e., unpaid voluntary work for social causes). We reasoned that family SES and work values might differentially affect these civic outcomes; for instance, low-SES individuals are typically less willing to give their money than to give their time (Verba et al., 1995).

To demonstrate the robustness and uniqueness of work values as a psychological mechanism linking family SES to civic engagement in young adulthood, we included a number of rival explanatory variables into our analyses. First, young individuals' current SES and employment status are typically associated with the SES of their family of origin, their work values, and civic engagement (i.e., status transmission; Johnson \& Mortimer, 2011; Verba et al., 1995; Wilson, 2012). Second, even though research has found only small associations between various work values and the Big Five personality dimensions (Leuty \& Hansen, 2012), work values may partly reflect broad personality dispositions which, in turn, have reliable associations with civic engagement (Lodi-Smith \& Roberts, 2007; Mondak, Hibbing, Canache, Seligson, \& Anderson, 2010). Third, the distinction between intrinsic and extrinsic work values partly maps 
to the concept of autonomous motivation (i.e., pursuing activities for their own sake or because they are important to the self) versus controlled motivation (i.e., feeling pressured to pursue an activity; Deci \& Ryan, 2008). Because autonomous motivation is related to prosocial behaviors, including civic engagement (Gagné, 2003), we considered it as a rival explanatory variable.

\section{Method}

\section{Sample and Procedure}

The FinEdu study (http://wiredminds.fi/projects/finedu/) comprises two master samples that first responded to a questionnaire in 2004 and then in 2005, 2006, 2008/09, 2011, and 2013/14. The first master sample included all ninth-grade students from all comprehensive schools (median age in 2004: 16 years) in a middle-sized Finnish city (population: 105,000). The second master sample comprised all second-year students from all upper secondary schools (median age in 2004: 18 years) from the same city. In 2004, this city's population (ca. 97,000) had very similar sociodemographic characteristics (e.g., average age, gender distribution, demographic dependency ratio, unemployment rate, religious affiliations, and common types of schools) to the overall Finnish population. However, this city had a slightly higher proportion of better educated individuals, but a lower average disposable income, than the general population (Statistics Finland, 2016).

At each wave, researchers tried to reach all of the individuals from the original master samples, including those who were not present at the first wave. While respondents were still in school (until 2006 and 2005 for the first and second sample, respectively), data collection took place in classrooms. After leaving school, respondents received postal or online questionnaires, and a small subset participated in telephone interviews. Efforts were made to motivate respondents to participate through raffles or vouchers, and repeated reminders. In line with 
Finnish laws and with institutional approval, researchers obtained passive parental consent and active student consent for study participation.

For the present study, we utilized data from both samples from the waves of 2004, 2011, and 2013/2014. The total number of respondents who participated in at least one of these three waves was 1,533 . Of those, 764 respondents were present at all three measurements. Attrition analyses showed that being a female and having a higher educational attainment significantly reduced the likelihood of dropout, effects that are typical of longitudinal studies. Online Table A1 provides detailed information on sample sizes and response rates for all waves.

\section{Measures}

Civic engagement. In 2013/2014, respondents reported how often they had engaged in a range of civic activities across the past two years $(1=$ never; $5=$ very often $)$. Three items referred to financial engagement (boycotting a product for political reasons; buying a product for political reasons; donating money to an organization or charity; $\alpha=.65)$. Three items referred to political activism (signing a petition; partaking in a political event; participating in a demonstration; $\alpha=.57)$. One item referred to volunteering (doing voluntary work).

Work values. We used eight items derived from the Meaning of Work Study (MOW International Research Team, 1987) administered in 2011. They asked respondents to indicate, on a 7-point-scale $(1=$ strongly disagree; 7 = strongly agree $)$, to what extent different job characteristics influenced their career choice ("My career choice is particularly influenced by the fact that the job offers...”). Extrinsic work values $(\alpha=.67)$ comprised "good pay"; "good opportunity for upgrading and promotions"; "convenient work hours and good physical working conditions"; and "work that has a promising view of future employment". Intrinsic work values $(\alpha=.75)$ comprised "interesting work"; "a lot of opportunity to learn new things and develop 
vocationally"; "a good match between job requirements and my abilities and strengths"; and "a lot of variety". Previous research attests to the criterion validity of these and similar items in predicting subjective and objective career-related outcomes (e.g., Johnson \& Mortimer, 2011; Sortheix et al., 2015; Taris \& Feij, 2001).

Family SES. Family SES was based on respondents' open-ended reports of their parents' occupations in 2004. Prior research supports the validity of adolescent reports of parental occupational status (Lien et al., 2001). Reports were coded according to a standard classification system (Official Statistics of Finland, 1989). We then recoded them into the following categories: 1 = blue-collar (e.g., electrician, baker, hairdresser); 2 =lower white-collar (e.g., nurse, real estate agent, salesperson); and 3 = upper white-collar (e.g., engineer, doctor, journalist). We coded parents who were self-employed $(n=114)$ in one of the three categories if the available information on their business/industry permitted it; otherwise, we assigned them a missing value. We also assigned a missing value to parents who were not employed (e.g., students, pensioners, the disabled; $n=261$ ). Overall, we were able to classify at least one parent into one of the three occupational status categories for 1,200 out of the 1,301 adolescents $(92 \%)$ who participated in the first wave, and for 908 (70\%) we could classify both parents. Among fathers, 35.0\% were blue-collar workers, $27.9 \%$ were lower white-collar workers, and 37.1\% were upper white-collar workers; among mothers, the numbers were $12.6 \%, 61.5 \%$ and $25.9 \%$, respectively. We used information on both parents' occupational status (Spearman's Rho $=.35$ ) to estimate a latent variable, as outlined in the Data Analysis section (analyses using the mean score or the highest value of two parents yielded almost identical results).

Personality traits. Traits were measured by a brief 15-item version of the Big Five Inventory administered in 2008 (John, Donahue, \& Kentle, 1991). Items were answered on a 
five-point rating scale. We computed two second-order personality factors often used in previous research (Digman, 1997; using five separate dimensions yielded the same substantive conclusions, but was less parsimonious). The "alpha" factor includes agreeableness, conscientiousness, and emotional stability $(\alpha=.65)$ - socially desirable traits that are required to enact adult social roles (Digman, 1997; Lodi-Smith \& Roberts, 2007). The "beta" factor comprises extraversion and openness to experience $(\alpha=.62)$ - traits that reflect an agentic, curious, and open personality (Digman, 1997).

Autonomous motivation. Respondents reported an open-ended personal goal related to education, career, or work in 2011. They were then asked to describe their motivation for pursuing this goal (Sheldon \& Kasser, 1995): extrinsic (“I'm pursuing this goal because somebody else wants me to or because the situation demands it"), introjected ("Because I'd feel ashamed, guilty or anxious if I did not"), identified (“Because I really believe it is an important goal"), and intrinsic ("Because of the enjoyment it gives me"), all rated on a 7-point scale $(1=$ not at all for this reason; $7=$ completely for this reason $)$. From these four items, we created an autonomous motivation index using the formula: $(2 \times$ intrinsic + identified $)-($ introjected + $2 \times$ external); to obtain only non-negative integers, we then added a constant $(+16)$. Higher values on this index reflect more autonomous motivation for pursuing one's educational or career goal (for similar approaches, see Vasalampi et al., 2014).

Individuals' own SES. We captured respondents' own SES and employment status in 2011 with three variables: a five-point indicator of educational track/attainment $(1=$ no upper secondary degree; 2 = completed one upper secondary degree; 3 = studying for or completed another upper secondary degree, such as a vocational school certificate; $4=$ studying for or completed a polytechnic institute degree; 5 = studying for or completed a university degree); a 
five-point item on financial difficulties ("How well does your income cover your expenses at present?"; 1 = extremely well; 5 = poorly $)$; and a binary indicator of employment status $(0=$ still in education or only part-time employed; 1 = employed full time).

Sociodemographic controls. We included binary indicators of the study sample $(0$ = comprehensive school sample; 1 = upper secondary school sample $)$ and gender $(0=$ male; $1=$ female $)$. In terms of family background variables, we controlled for whether respondents were living with both biological parents in adolescence $(0=n o ; 1=y e s)$, their current relationship status $(0=$ single $; 1=$ romantic relationship, including marriage $)$, and parenthood $(0=$ no children; $1=$ at least one child $)$. We took information on gender, study sample, and living with both biological parents from the 2004 wave and information on all other control variables from 2011.

\section{Data Analysis}

We used structural equation modeling (SEM) in Mplus 7.3 to test our hypotheses. First, we set up a measurement model with parental occupational status, extrinsic and intrinsic job rewards, financial engagement, and political activism as latent variables. We also included the single-item measure of volunteering in the model to ensure that modelling it separately was permissible (as judged by model fit and modification indices). We treated the manifest indicators of parental occupational status and civic engagement as ordered categorical variables, invoking the robust weighted least squares (WLS) estimator (i.e., WLSMV in Mplus). WLS does not assume normality and is the method of choice for modeling ordered categorical data, especially when sample size exceeds 200 . We considered model fit to be acceptable when at least two out of the four commonly used fit indices were in the range conventionally considered to be acceptable (i.e., $\chi^{2}$ non-significant or at least within a four-to-one ratio to the $d f$; CFI and 
TLI $>.90$, RMSEA $<.06$, WRMR $<1)$. According to these criteria, the measurement model showed reasonable fit to the data, $\chi^{2}(104)=342.21, p<.001, C F I=.94, T L I=.93$, $R M S E A=.039, \mathrm{CI}_{90 \%}=[.035, .044], W R M R=1.212$. As suggested by model modification indices, this model included one residual correlation between the first and second indicator of extrinsic work values ("good pay" and "good opportunity for upgrading and promotion"); including this correlation did not alter any of the substantive conclusions from subsequent analyses. All standardized loadings in the measurement model were greater than .50 , except those of the first indicator of financial engagement $(\lambda=.49)$ and the third indicator of extrinsic work values $(\lambda=.40)$.

Our structural model (see Figure 1) was one in which parental socioeconomic status (family SES), sociodemographic controls, and respondents' own SES in 2011 predicted work values. Family SES, controls, work values, and other explanatory variables (respondents' own SES in 2011, personality, and autonomous motivation) predicted the three types of civic engagement.

Work values and the other rival predictors of civic engagement were allowed to correlate. In order to test the mediational chain from parental occupational status to civic engagement through work values, we used a bootstrap with 1,000 random draws to obtain biascorrected bootstrapped confidence intervals for indirect effects. We handled all missing data, including those caused by longitudinal attrition, with the full information maximum likelihood (FIML) algorithm. Thus, our analyses always used all available information from the entire sample, although not all respondents provided data on all measures at all waves. Table 1 provides descriptive statistics on all study variables and missing data information.

\section{Results}


Table 2 provides mediation results, and Figure 1 shows the SEM paths relevant to our hypotheses (for detailed regression results, see online Tables A2 and A3). As predicted by Hypothesis 1, a lower parental occupational status in 2004 predicted lower financial engagement, political activism, and volunteering in 2013/2014 — above and beyond the effects of sociodemographic control variables and other rival predictors (young adults' own SES, personality, and autonomous motivation) ("total effects" in Table 2). Descriptively, the strength of this linkage appeared strongest for political engagement and weakest for volunteering.

Furthermore, in support of Hypothesis 2a, a lower parental occupational status in 2004 predicted higher importance of extrinsic job rewards among young adults in 2011 above and beyond the effects of all sociodemographic factors. The effect size was small: parental occupational status explained slightly above $2 \%$ of the variance in extrinsic work values in a model without covariates (not shown). Contrary to Hypothesis $2 \mathrm{~b}$, parental occupational status did not significantly predict valuing intrinsic job rewards (only $0.1 \%$ of variance explained).

In line with Hypothesis 3a, valuing extrinsic job rewards predicted lower civic engagement above and beyond the effects of parental occupational status and rival explanatory variables (see Figure 1). This was true for all three types of engagement. A Wald test showed that the effect of extrinsic work values was significantly stronger on political activism than on financial engagement, $\chi^{2}(1)=10.41, p<.01$ (no such comparison was possible for volunteering because of its different metric). In turn, and in line with Hypothesis 3b, valuing intrinsic job rewards predicted higher civic engagement for all its types. In a model without the covariates (not shown), parental occupational status and work values together explained $18 \%$ of the variance in financial engagement, $31 \%$ of the variance in political activism, and $10 \%$ of the variance in volunteering. 
Finally, concordant with Hypothesis 4, valuing extrinsic job rewards mediated the effects of parental occupational status on all three types of civic engagement, as indicated by the indirect effects shown in Table 2. The direct effects of parental occupational status were statistically significant for financial engagement and political activism, but not for volunteering (see Figure 1 and Table 2). However, valuing intrinsic job rewards did not mediate the effects of parental occupational status on the three types of civic engagement. In sum, the results supported our key hypothesis that work values mediate the linkage between parental occupational status and later civic engagement for extrinsic, but not for intrinsic, work values as a mediator. Across the three outcomes, the mediation effect appeared strongest for political engagement.

Regarding the rival explanations of the effects of work values on civic engagement, only personality (in particular, the beta factor comprising extraversion and openness to experience) consistently predicted all types of civic engagement. The alpha factor (consisting of agreeableness, conscientiousness, and emotional stability) was a significant predictor of lower political activism. Neither autonomous motivation in pursuing educational or occupational goals nor youth's own SES and employment status had significant effects on later civic engagement. However, one exception was found, in which financial difficulties in 2011 (one indicator of youth's own SES) significantly predicted higher political activism in 2013/2014. This unexpected effect was very small. As already explained, the effects of work values on civic engagement held after these covariates were included in the model.

\section{Discussion}

This study investigated whether work values mediate the link between family SES and civic engagement during the transition to adulthood. We drew on the SOC model (Baltes, 1997; Riediger \& Freund, 2004; Wiese \& Salmela-Aro, 2008) to argue that lower-SES youth, who 
often place more value on extrinsic job rewards (i.e., salary, status, and job security) than do higher-SES youth, will view civic engagement as incompatible with their career priorities and will therefore be less likely to become civically engaged. To test this idea, we used data from a 10-year longitudinal Finnish study. We found support for most paths in the proposed mediational model (see Figure 1).

First, youth from lower-SES families more strongly endorsed extrinsic work values (i.e., agreed that their career choice was influenced by extrinsic job rewards) than did their higher-SES counterparts. This finding is consistent with previous research suggesting that low-SES parents pass on extrinsic work values to their children through early socialization (Kohn \& Schooler, 1969) and that materialistic concerns increase under conditions of economic deprivation (Kasser, Ryan, Couchman, \& Sheldon, 2004). Contrary to our expectations, family SES was unrelated to valuing intrinsic job rewards (i.e., interest, variety, and self-realization at work). Recent research yielded similar null findings (Johnson \& Mortimer, 2011; Sortheix et al., 2015). At least in Western societies, aspiring for an interesting and fulfilling job appears to be near-universal for young people, irrespective of their family socioeconomic backgrounds. Social desirability might have also influenced our participants' reports, because students may be more likely to report that they chose a job or career because it offers learning opportunities and is interesting, rather than because it provides a good salary and convenient work hours.

Second, young adults who placed more value on extrinsic job rewards reported lower civic engagement two years later. Previous research found that focusing on paid work as a means of achieving material wealth and security, as reflected by extrinsic work values, can be beneficial for some career outcomes, e.g., earnings (Johnson \& Mortimer, 2011). However, it was also found that extrinsic work values can lead to a conflict between paid work and other life roles 
(i.e., family; Vansteenkiste et al., 2007). Our results contribute to this evidence, extending it to the civic domain, and thus point to a "dark side" of extrinsic work values. In contrast, intrinsic work values were a positive predictor of all three types of civic engagement (cf. Johnson et al., 1998). This is in line with the intrinsic work values' positive outcomes in the work context: intrinsic work values in young adults were longitudinally related to sustained work motivation (Sortheix, Dietrich, Chow, \& Salmela-Aro, 2013), and evaluating one's job as matching one's skills and interests two years later (Sortheix et al., 2015). As we argued earlier, the wellestablished fact that young labor market entrants sometimes become civically engaged in order to improve their career chances (Clary \& Snyder, 1999; Hustinx et al., 2010; Pavlova \& Silbereisen, 2014; Wilson, 2012) may pertain primarily to those youth who seek opportunities for learning, skill use, and personal growth in their jobs. They will tend to regard civic engagement as an activity that resonates with their career goals. Indeed, civic engagement is thought to provide plentiful opportunities for acquiring soft skills (e.g., public speaking, negotiating, and event organizing), meeting new people, and exploring occupational roles, e.g., that of a social worker (Ruiter \& De Graaf, 2009; Verba et al., 1995; Wilson \& Musick, 2003).

Finally, extrinsic work values partly mediated the link between parental occupational status assessed in adolescence and civic engagement in young adulthood. Although the indirect effects were small, it should be noted that the total effects of family SES on civic engagement were themselves quite small and that 10 years elapsed between the assessment of the predictor and the outcome. Effect sizes also compared favorably to the very small effects of other psychological mediators reported from prior research (Brown \& Lichter, 2007; Carlo et al., 2011). However, intrinsic work values were not significant mediators in our study because, as explained above, they were not predicted by family SES. 
As our analyses including rival explanatory variables of civic engagement showed, the effects of work values could not be attributed to sociodemographic variables, to young adults' own SES (educational attainment, employment status, and financial situation), to their personality traits, or to their autonomous versus controlled motivation in pursuing educational or career goals. Thus, our study offers compelling evidence for unique, specific effects of extrinsic and intrinsic work values on civic engagement in young adulthood. Among the covariates, personality characteristics (in particular, the beta factor comprising openness to experience and extraversion) emerged as a consistent predictor of later civic engagement, which was in line with prior research (Mondak et al., 2010). However, respondents' own educational attainment, employment status, and financial difficulties hardly had any bearing on civic engagement reported two years later. One explanation for this lack of effects could be that young adults' status attainment is still in flux. When their own SES was assessed, our respondents were aged 23-25 years; as is typical in Finland, many were still in post-secondary or tertiary education, and only one-third of them worked full-time. The finding that indicators of young adults' own SES did not predict their civic engagement is also relevant given the possible argument that lowerSES individuals typically work in more precarious jobs (Johnson \& Mortimer, 2011; Sortheix et al., 2013) and may not have sufficient time or money to participate in other life roles.

To return to the main findings, of the three outcomes, political activism was best explained by the predictors, which altogether accounted for more than $40 \%$ of its variance. In particular, extrinsic work values had significantly stronger effects on political activism than on financial engagement. This finding may seem surprising, because one might expect that individuals who seek material security will be most reluctant to donate their money, but not that reluctant to donate their time, to political causes (Verba et al., 1995). However, financial 
engagement often addresses very specific issues (e.g., building shelters for homeless pets or organizing a local sporting event), which are readily understandable to the majority of individuals. In contrast, political activism may depend more on a broader awareness of political and societal issues that is less likely to be developed in individuals coming from low SES families, and who value material and more immediate aspects of their work (Kohn \& Schooler, 1969). Furthermore, in our study, the frequencies of participating in a demonstration or in a political event were very low. Research has shown that the less normative a behavior, the more it can be influenced by personal values (Bardi \& Schwartz, 2003). As suggested by our results, this relation may hold even for cross-domain links between values at work and civic behavior.

Finally, compared to the other two types of engagement, volunteering appeared to be less well explained by the variables in the model (see Figure 1 and Table A3). However, this finding might have a purely technical reason: with a single-item measure of volunteering, we could not correct for measurement error. In addition, a single item inevitably had a lower variance than multiple-item indicators of political activism and financial engagement.

\section{Practical Implications in the Finnish Context and Beyond}

It may appear to be a rational decision for low-SES youth to focus on paid employment in order to gain material security and to avoid secondary pursuits, e.g., civic engagement. With unemployment rates among young Finns between 25 and 34 years of age reaching up to $28.6 \%$ (Statistics Finland, 2016), the transition from school to work has become more difficult in Finland. This precarious situation may make paid work and its extrinsic rewards highly salient to Finnish youth, especially if they come from low-SES families. Moreover, the benefits of civic engagement to occupational careers are less evident in Finland than in certain countries, such as the U.S. and Canada, where information on volunteering experience is routinely added to one's 
$\mathrm{CV}$, and is actually used by educational institutions and employers in their admission or hiring decisions (Hustinx et al., 2010; Wilson \& Musick, 2003). In Finland, civic engagement is not commonly seen as labor-market relevant (Hustinx et al., 2010).

However, civic engagement does not only bring socioeconomic payoffs in North American countries. For instance, Ruiter and De Graaf (2009) reported substantial effects of voluntary memberships and volunteering on later occupational status and earnings in the Netherlands, which is closer to Finland than to the U.S. in terms of its political and welfare system. It stands to reason that youth who value extrinsic job rewards could nevertheless be drawn into civic engagement, were they aware of its indirect material benefits. Although civic engagement of such individuals could initially be driven by selfish motives, youth may discover other benefits and develop other motivations (e.g., altruistic) in the course of their participation (Hustinx et al., 2010; Johnson et al., 1998). Therefore, to reduce SES disparities in youth civic participation in Finland and elsewhere, policy-makers might consider disseminating information on the tangible benefits of civic engagement (i.e., occupational status and earnings), in addition to presenting its intangible career-related benefits, e.g., learning and exploration of career opportunities. These two kinds of messages would speak to different types of values that youth attach to paid work. Educational institutions could also work to strengthen their links to nonprofit associations and to shape youth perceptions of civic engagement as a valuable activity that could assist them in the transition to work.

\section{Limitations and Future Directions}

Some limitations of our study should be noted. As with all correlational research, we cannot establish causality. Even though our 10-year longitudinal design helped to ascertain the direction of effects, the only viable means of establishing a causal link between work values and 
civic engagement would be to conduct a randomized control trial that manipulates young people's work values and traces their effects on civic engagement.

Furthermore, our study was based on self-report data alone, which may lead to common method bias. Although it would be difficult to obtain accurate information on work values through a method other than self-report, future studies could benefit from using parent-reported SES measures and from obtaining information on respondents' civic engagement from other sources, e.g., peers or voluntary organizations. Moreover, our volunteering item was quite unspecific (e.g., it neither gave a definition of volunteering nor provided examples); this may have led respondents to under-report volunteer activities, rendering this a conservative measure of volunteering. It is also worth noting that we measured family SES in 2004 when respondents were adolescents; even though there is typically a strong continuity in SES within the same family, this measure may not necessarily represent family SES during the formative childhood years. Hence, this measure did not permit us to determine whether family SES has its most decisive effect on offspring's later work values and engagement already during childhood or later. Nevertheless, this measure was able to predict offspring's civic engagement 10 years later. Our analyses also included respondents from one nation only, and we cannot be certain whether our results generalize to other national contexts. On the one hand, the Finnish context of low socioeconomic inequality could have diminished the impact of family SES on youth civic engagement, leading us to expect even stronger effects in other contexts. On the other hand, the years between 2011 and 2014 were a period of an economic downturn in Finland. It is possible that extrinsic work values were more salient and had stronger effects on psychosocial outcomes for this cohort of Finns than for cohorts who entered the labor market in times of economic prosperity. In fact, there is recent evidence showing that the period of economic recession has 
increased the importance of security and wealth across Europe (Sortheix, Parker, Lechner, \& Schwartz, March, 2016). Furthermore, in other national contexts, where career-related benefits of civic engagement are more obvious (Hustinx et al., 2010; Wilson \& Musick, 2003), valuing extrinsic job rewards may not lead young individuals to opt out of civic engagement. Future research should therefore address similar research questions in other national contexts.

Finally, future studies could identify more direct ways of testing our idea that, depending on their work values, young individuals view civic engagement as more or less useful to their careers. For instance, perceived benefits of different types of civic engagement could be assessed and linked to the importance of intrinsic, extrinsic, and also other types of work values.

\section{Conclusions}

Our 10-year longitudinal study offers first evidence showing that extrinsic work values (i.e., the importance attached to job security and material rewards) are a psychological mechanism that partly explains the link between a lower family SES and lower civic engagement in young adulthood. This novel finding contributes to a better understanding of the "long arm" of family socioeconomic conditions in shaping later civic engagement. In contrast, intrinsic work values fostered civic engagement, demonstrating their relevance for outcomes beyond the work context; however, they were unrelated to family SES. Thus, extrinsic work values hold promise as mediators between family SES and other types of career and non-career outcomes. 


\section{References}

American Psychological Association (APA). (2015). Civic engagement. Retrieved August 20, 2015, from http://www.apa.org/education/undergrad/civic-engagement.aspx

Baltes, P. B. (1997). On the incomplete architecture of human ontogeny: Selection, optimization, and compensation as foundation of developmental theory. American Psychologist, 52, 366-380. doi:10.1037/0003-066X.52.4.366

Bardi, A., \& Schwartz, S. H. (2003). Values and behavior: Strength and structure of relations. Personality and Social Psychology Bulletin, 29(10), 1207-1220. doi:10.1177/0146167203254602

Brown, J. B., \& Lichter, D. T. (2007). Childhood disadvantage, adolescent development, and pro-social behavior in early adulthood. Advances in Life Course Research, 11, 149-170. doi:10.1016/S1040-2608(06)11006-0

Carlo, G., Padilla-Walker, L. M., \& Day, R. D. (2011). A test of the economic strain model on adolescents' prosocial behaviors. Journal of Research on Adolescence, 21(4), 842-848. doi:10.1111/j.1532-7795.2011.00742.x

Clary, E. G., \& Snyder, M. (1999). The motivations to volunteer: Theoretical and practical considerations. Current Directions in Psychological Science, 8, 156-159. doi:10.1111/1467-8721.00037

Deci, E. L., \& Ryan, R. M. (2008). Facilitating optimal motivation and psychological well-being across life's domains. Canadian Psychology, 49, 14-23.

Flanagan, C. (2003). Developmental roots of political engagement. Political Science and Politics, 36(2), 257-261. doi:10.1017/S104909650300218X 
Flanagan, C., \& Levine, P. (2010). Civic engagement and the transition to adulthood. The Future of Children, 20(1), 159-179. doi:10.1353/foc.0.0043

Gagné, M. (2003). The role of autonomy support and autonomy orientation in prosocial behavior engagement. Motivation and Emotion, 27, 199-223. doi:10.1023/A:1025007614869

Hurst, M., Dittmar, H., Bond, R., \& Kasser, T. (2013). The relationship between materialistic values and environmental attitudes and behaviors: A meta-analysis. Journal of Environmental Psychology, 36, 257-269. doi:10.1016/j.jenvp.2013.09.003

Hustinx, L., Handy, F., Cnaan, R. A., Brudney, J. L., Pessi, A. B., \& Yamauchi, N. (2010). Social and cultural origins of motivations to volunteer: A comparison of university students in six countries. International Sociology, 25(3), 349-382. doi:10.1177/0268580909360297

Janoski, T., \& Wilson, J. (1995). Pathways to voluntarism: Family socialization and status transmission models. Social Forces, 74(1), 271-292. doi:10.2307/2580632

Johnson, M. K., Beebe, T., Mortimer, J. T., \& Snyder, M. (1998). Volunteerism in adolescence: A process perspective. Journal of Research on Adolescence, 8, 309-332. doi:10.1207/s15327795jra0803_2

Johnson, M. K., \& Monserud, M. A. (2012). Work value development from adolescence to adulthood. Advances in Life Course Research, 17(2), 45-58.

Johnson, M. K., \& Mortimer, J. T. (2011). Origins and outcomes of judgments about work. Social Forces, 89(4), 1239-1260. doi:10.1093/sf/89.4.1239

Kasser, T., Ryan, R. M., Couchman, C. E., \& Sheldon, K. M. (2004). Materialistic values: Their causes and consequences. In T. Kasser \& A. D. Kanner (Eds.), Psychology and consumer 
culture: The struggle for a good life in a materialistic world (pp. 11-28). Washington, DC, US: American Psychological Association.

Kohn, M. L., \& Schooler, C. (1969). Class, occupation, and orientation. American Sociological Review, 34(5), 659-678. doi:10.2307/2092303

Leuty, M. E., \& Hansen, J.-I. C. (2012). Building evidence of validity: The relation between work values, interests, personality, and personal values. Journal of Career Assessment, 21, 175-189. doi:10.1177/1069072712466714

Levinson, M. (2010). The civic empowerment gap: Defining the problem and locating solutions. In L. R. Sherrod, J. Torney-Purta, \& C. A. Flanagan (Eds.), Handbook of research on civic engagement in youth (pp. 331-361). Hoboken, NJ: Wiley.

Lien, N., Friestad, C., \& Klepp, K.-I. (2001). Adolescents’ proxy reports of parents’ socioeconomic status: How valid are they? Journal of Epidemiology and Community Health, 55(10), 731-737. doi:10.1136/jech.55.10.731

Lodi-Smith, J., \& Roberts, B. W. (2007). Social investment and personality: A meta-analysis of the relationship of personality traits to investment in work, family, religion, and volunteerism. Personality and Social Psychology Review, 11, 68-86. doi:10.1177/1088868306294590

Mondak, J. J., Hibbing, M. V., Canache, D., Seligson, M. A., \& Anderson, M. R. (2010). Personality and civic engagement: An integrative framework for the study of trait effects on political behavior. American Political Science Review, 104, 85-110. doi:10.1017/S0003055409990359

MOW International Research Team. (1987). The meaning of working. London: Academic Press. 
Mustillo, S., Wilson, J., \& Lynch, S. M. (2004). Legacy volunteering: A test of two theories of intergenerational transmission. Journal of Marriage and Family, 66(2), 530-541. doi:10.1111/j.1741-3737.2004.00036.x

Oesterle, S., Johnson, M. K., \& Mortimer, J. T. (2004). Volunteerism during the transition to adulthood: A life course perspective. Social Forces, 82(3), 1123-1149. doi:10.1353/sof.2004.0049

Official Statistics of Finland. (1989). Sosioekonominen luokitus [Classification of socioeconomic groups]. Helsinki: Statistics Finland.

Pavlova, M. K., \& Silbereisen, R. K. (2014). Coping with occupational uncertainty and formal volunteering across the life span. Journal of Vocational Behavior, 85(1), 93-105. doi:10.1016/j.jvb.2014.05.005

Quigley, N. R., \& Tymon Jr, W. G. (2006). Toward an integrated model of intrinsic motivation and career self-management. Career Development International, 11(6), 522-543.

Riediger, M., \& Freund, A. M. (2004). Interference and facilitation among personal goals: Differential associations with subjective well-being and persistent goal pursuit. Personality and Social Psychology Bulletin, 30, 1511-1523. doi:10.1177/0146167204271184

Ros, M., Schwartz, S. H., \& Surkiss, S. (1999). Basic individual values, work values, and the meaning of work. Applied Psychology, 48(1), 49-71. doi:10.1111/j.14640597.1999.tb00048.x

Ruiter, S., \& De Graaf, N. D. (2009). Socio-economic payoffs of voluntary association involvement: A Dutch life course study. European Sociological Review, 25(4), 425-442. doi:10.1093/esr/jen051 
Sheldon, K. M., \& Kasser, T. (1995). Coherence and congruence: two aspects of personality integration. Journal of personality and social psychology, 68(3), 531-543.

Sortheix, F. M., Chow, A., \& Salmela-Aro, K. (2015). Work values and the transition to work life: A longitudinal study. Journal of Vocational Behavior, 89, 162-171. doi:10.1016/j.jvb.2015.06.001

Sortheix, F. M., Dietrich, J., Chow, A., \& Salmela-Aro, K. (2013). The role of career values for work engagement during the transition to working life. Journal of Vocational Behavior, $83(3), 466-475$.

Sortheix, F. M., Parker, P., Lechner, C. M., \& Schwartz, S. H. (2016, March). Personal value change in young adults in response to the global financial crisis in Europe. Poster presented at the biennial meeting of the Pathways to Adulthood Postdoctoral Program, London, UK.

Statistics Finland. (2016). Statistical databases. Retrieved from http://stat.fi/tup/tilastotietokannat/index_en.html

Taris, R., \& Feij, J. (2001). Longitudinal examination of the relationship between supplies-values fit and work outcomes. Applied Psychology, 50(1), 52-80. doi:10.1111/1464-0597.00048

Vansteenkiste, M., Neyrinck, B., Niemiec, C. P., Soenens, B., De Witte, H., \& Van den Broeck, A. (2007). On the relations among work value orientations, psychological need satisfaction and job outcomes: A self-determination theory approach. Journal of Occupational and Organizational Psychology, 80(2), 251-277. doi:10.1348/096317906X111024

Vasalampi, K., Parker, P., Tolvanen, A., Lüdtke, O., Salmela-Aro, K., \& Trautwein, U. (2014). Integration of personality constructs: The role of traits and motivation in the willingness 
to exert effort in academic and social life domains. Journal of Research in Personality, 48, 98-106.

Verba, S., Schlozman, K. L., \& Brady, H. E. (1995). Voice and equality: Civic voluntarism in American politics. Cambridge, MA: Harvard University Press.

Wiese, B. S., \& Salmela-Aro, K. (2008). Goal conflict and facilitation as predictors of workfamily satisfaction and engagement. Journal of Vocational Behavior, 73(3), 490-497.

Wilson, J. (2012). Volunteerism research: A review essay. Nonprofit and Voluntary Sector Quarterly, 41(2), 176-212. doi:10.1177/0899764011434558

Wilson, J., \& Musick, M. A. (2003). Doing well by doing good: Volunteering and occupational achievement among American women. The Sociological Quarterly, 44, 433-450. doi:10.1111/j.1533-8525.2003.tb00540 
FAMILY SES, WORK VALUES, AND CIVIC ENGAGEMENT

Table 1

Descriptive Statistics and Missing Data Information for All Study Variables

\begin{tabular}{|c|c|c|c|c|}
\hline Variables & Range & $\begin{array}{c}M(S D) \\
\text { or } \%\end{array}$ & $\begin{array}{c}\text { missing } \\
\text { total }^{\mathrm{a}}, \%\end{array}$ & $\begin{array}{l}\text { missing } \\
\text { item }^{\text {b }} \%\end{array}$ \\
\hline \multicolumn{5}{|l|}{ Parental occupational status 2004} \\
\hline Mother's & $1-3$ & $2.1(0.6)$ & 33.4 & 17.8 \\
\hline Father's & $1-3$ & $2.0(0.8)$ & 40.1 & 26.1 \\
\hline \multicolumn{5}{|l|}{ Work values 2011} \\
\hline Good pay & $1-7$ & $4.8(1.4)$ & 34.1 & 3.2 \\
\hline Good opportunity for upgrading and promotion & $1-7$ & $4.6(1.5)$ & 34.2 & 3.4 \\
\hline Work hours and physical working conditions & $1-7$ & $5.4(1.5)$ & 34.6 & 4.0 \\
\hline Promising view of future employment & $1-7$ & $5.4(1.4)$ & 34.9 & 4.4 \\
\hline Interesting work & $1-7$ & $6.5(0.8)$ & 33.9 & 3.0 \\
\hline Learning opportunities & $1-7$ & $6.0(1.1)$ & 34.1 & 3.3 \\
\hline Match between job requirements and abilities & $1-7$ & $6.1(0.9)$ & 34.0 & 3.1 \\
\hline Variety & $1-7$ & $5.9(1.1)$ & 33.9 & 3.0 \\
\hline \multicolumn{5}{|l|}{ Civic engagement 2014} \\
\hline Boycotting a product for political reasons & $1-5$ & $2.3(1.3)$ & 34.5 & 7.4 \\
\hline Buying a product for political reasons & $1-5$ & $2.7(1.3)$ & 34.5 & 7.4 \\
\hline Donating money to an organization or charity & $1-5$ & $2.3(1.2)$ & 34.2 & 7.0 \\
\hline Signing a petition & $1-5$ & $2.3(1.1)$ & 34.4 & 7.3 \\
\hline Participating in a political event & $1-5$ & $1.4(0.8)$ & 34.7 & 7.7 \\
\hline Participating in a demonstration & $1-5$ & $1.2(0.5)$ & 34.4 & 7.3 \\
\hline Doing voluntary work & $1-5$ & $1.7(1.1)$ & 34.4 & 7.2 \\
\hline \multicolumn{5}{|l|}{ Covariates } \\
\hline Upper secondary school sample & $0-1$ & 47.2 & - & - \\
\hline Female & $0-1$ & 55.1 & .1 & .4 \\
\hline Educational track/attainment 2011 & $1-5$ & $3.8(1.2)$ & 32.7 & 1.2 \\
\hline Full-time employment 2011 & $0-1$ & 32.8 & 33.1 & 1.7 \\
\hline Financial difficulties 2011 & $0-5$ & $2.8(1.2)$ & 33.3 & 2.1 \\
\hline Living with both parents 2004 & $0-1$ & 67.7 & 19.4 & 18.4 \\
\hline Steady relationship 2011 & $0-1$ & 66.3 & 32.1 & .3 \\
\hline Parenthood 2011 & $0-1$ & 7.8 & 32.2 & .5 \\
\hline Autonomous motivation 2011 & $0-34$ & $25.6(6.7)$ & 30.1 & 3.2 \\
\hline Personality alpha 2008 & $1-5$ & $3.5(0.5)$ & 36.9 & 5.0 \\
\hline Personality beta 2008 & $1-5$ & $3.5(0.6)$ & 36.9 & 5.0 \\
\hline
\end{tabular}

Note. ${ }^{a}$ Refers to missing data due to non-participation in the respective wave and item non-response combined; ${ }^{b}$ refers to missing data due to item non-response among those who participated in the respective wave. 
Table 2

Mediation Analyses

\begin{tabular}{|c|c|c|c|c|c|c|c|c|c|}
\hline \multirow[b]{2}{*}{ Effect of parental occupational status } & \multicolumn{3}{|c|}{$\begin{array}{l}\text { Financial engagement } \\
2013 / 14\end{array}$} & \multicolumn{3}{|c|}{$\begin{array}{c}\text { Political activism } \\
2013 / 14\end{array}$} & \multicolumn{3}{|c|}{$\begin{array}{c}\text { Volunteering } \\
2013 / 14\end{array}$} \\
\hline & $b$ & $\mathrm{CI}_{95 \%}$ & $\beta$ & $b$ & $\mathrm{CI}_{95 \%}$ & $\beta$ & $b$ & $\mathrm{CI}_{95 \%}$ & $\beta$ \\
\hline Total effect & $0.18 * *$ & {$[0.06,0.31]$} & 0.22 & $0.48 * * *$ & {$[0.23,0.77]$} & 0.34 & $0.22 *$ & {$[0.08,0.36]$} & 0.15 \\
\hline Direct effect & $0.13^{*}$ & {$[0.00,0.25]$} & 0.16 & $0.37 * *$ & {$[0.11,0.66]$} & 0.26 & 0.16 & {$[-0.02,0.29]$} & 0.09 \\
\hline \multicolumn{10}{|l|}{ Indirect effects } \\
\hline Total indirect & $0.05^{*}$ & {$[0.01,0.11]$} & 0.06 & $0.11^{*}$ & {$[0.02,0.24]$} & 0.08 & $0.06^{*}$ & {$[0.01,0.13]$} & 0.06 \\
\hline Via extrinsic rewards & $0.05^{*}$ & {$[0.01,0.11]$} & 0.07 & $0.12 *$ & {$[0.02,0.24]$} & 0.09 & $0.07 *$ & {$[0.01,0.14]$} & 0.06 \\
\hline Via intrinsic rewards & -0.00 & {$[-0.04,0.01]$} & -0.01 & -0.01 & {$[-0.09,0.01]$} & -0.01 & -0.01 & {$[-0.05,0.02]$} & -0.01 \\
\hline
\end{tabular}

$* p<.05, * * p<.01, * * * p<.001$.

Note. Confidence intervals for unstandardized coefficients $(b)$ from a bias-corrected bootstrap with 1,000 random draws. 

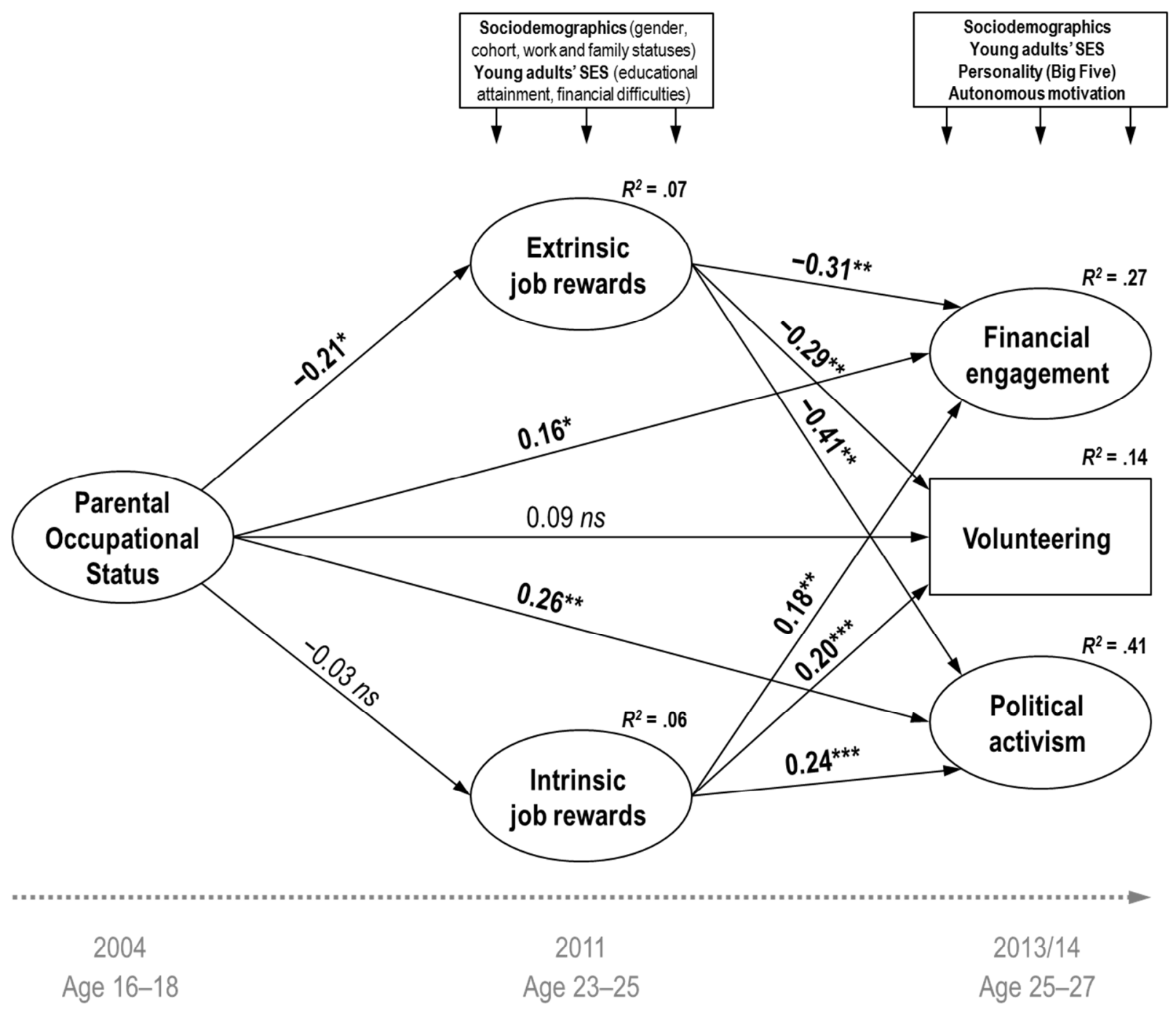

Figure 1. Results from a structural equation model testing the mediating role of work values in the relationship between parental occupational status and later civic engagement. Coefficients are standardized regression coefficients $(\beta)$. Effects of covariates and manifest indicators of latent variables are omitted for clarity.

$* p<.05, * * \mathrm{p}<.01,{ }^{* * *} \mathrm{p}<.001$ 
FAMILY SES, WORK VALUES, AND CIVIC ENGAGEMENT

\section{Appendix}

Table A1

Survey Participation Information

\begin{tabular}{lccc}
\hline Indicator & 2004 & 2011 & $2013 / 14$ \\
\hline$N$ & 1,301 & 1,096 & 1,138 \\
$n$ present at $1^{\text {st }}$ wave & 1,301 & 901 & 941 \\
Response rate, \% & 75.6 & 63.7 & 66.1 \\
Present at $1^{\text {st }}$ wave, \% & 100.0 & 69.3 & 72.3 \\
\hline
\end{tabular}

URL: https://mc.manuscriptcentral.com/ads E-mail: iaryd.pubs@gmail.com 
FAMILY SES, WORK VALUES, AND CIVIC ENGAGEMENT

Table A2

Detailed Regression Results for the Path from Parental Occupational Status to Work Values

\begin{tabular}{|c|c|c|c|c|c|c|}
\hline \multirow[b]{2}{*}{ Predictor } & \multicolumn{3}{|c|}{$\begin{array}{l}\text { Extrinsic rewards } \\
2011\end{array}$} & \multicolumn{3}{|c|}{ Intrinsic rewards 2011} \\
\hline & $b$ & $S E$ & $\beta$ & $b$ & $S E$ & $\beta$ \\
\hline \multicolumn{7}{|l|}{ Focal predictor } \\
\hline Parental occupational status 2004 & $-0.26^{*}$ & 0.11 & -0.21 & -0.02 & 0.06 & -0.03 \\
\hline \multicolumn{7}{|l|}{ Sociodemographic control variables } \\
\hline Upper secondary school sample & -0.11 & 0.07 & -0.07 & -0.03 & 0.04 & -0.03 \\
\hline Female & -0.05 & 0.07 & -0.03 & $0.20 * * *$ & 0.04 & 0.18 \\
\hline Educational track/attainment 2011 & $0.14 * * *$ & 0.04 & 0.21 & $0.07 * * *$ & 0.02 & 0.15 \\
\hline Full-time employment 2011 & 0.10 & 0.08 & 0.06 & 0.01 & 0.04 & 0.00 \\
\hline Financial difficulties 2011 & 0.01 & 0.03 & 0.01 & -0.01 & 0.02 & -0.02 \\
\hline Living with both parents 2004 & 0.12 & 0.08 & 0.08 & 0.04 & 0.04 & 0.04 \\
\hline Steady relationship 2011 & 0.13 & 0.07 & 0.08 & 0.05 & 0.04 & 0.04 \\
\hline Parenthood 2011 & 0.15 & 0.12 & 0.05 & -0.04 & 0.07 & -0.02 \\
\hline$R^{2}$ & & $0.07 *$ & & & $0.06^{*}$ & \\
\hline
\end{tabular}

$* p<.05, * * p<.01, * * * p<.001$. 
FAMILY SES, WORK VALUES, AND CIVIC ENGAGEMENT

Table A3

Detailed Regression Results for the Paths from Parental Occupational Status and Work Values to Civic Engagement

\begin{tabular}{|c|c|c|c|c|c|c|c|c|c|}
\hline \multirow[b]{2}{*}{ Predictor } & \multicolumn{3}{|c|}{$\begin{array}{l}\text { Financial engagement } \\
2013 / 14\end{array}$} & \multicolumn{3}{|c|}{$\begin{array}{c}\text { Political activism } \\
\text { 2013/14 }\end{array}$} & \multicolumn{3}{|c|}{$\begin{array}{c}\text { Volunteering } \\
\text { 2013/14 }\end{array}$} \\
\hline & $b$ & $S E$ & $\beta$ & $b$ & $S E$ & $\beta$ & $b$ & $S E$ & $\beta$ \\
\hline \multicolumn{10}{|l|}{ Focal predictors } \\
\hline Parental occupational status 2004 & $0.13 *$ & 0.06 & 0.16 & $0.36^{* *}$ & 0.12 & 0.26 & 0.15 & 0.13 & 0.09 \\
\hline Intrinsic job rewards 2011 & $0.17 * *$ & 0.06 & 0.18 & $0.39 * *$ & 0.13 & 0.24 & $0.37 * *$ & 0.12 & 0.20 \\
\hline Extrinsic job rewards 2011 & $-0.20 * * *$ & 0.04 & -0.31 & $-0.46^{* * *}$ & 0.10 & -0.41 & $-0.37 * * *$ & 0.09 & -0.29 \\
\hline \multicolumn{10}{|l|}{ Covariates } \\
\hline Upper secondary school sample & 0.04 & 0.04 & 0.04 & 0.08 & 0.08 & 0.05 & 0.05 & 0.09 & 0.03 \\
\hline Female & $0.19 * * *$ & 0.04 & 0.18 & 0.09 & 0.08 & 0.06 & 0.04 & 0.08 & 0.02 \\
\hline Educational track/attainment 2011 & 0.04 & 0.02 & 0.09 & 0.01 & 0.05 & 0.00 & 0.01 & 0.05 & 0.00 \\
\hline Full-time employment 2011 & 0.02 & 0.05 & 0.02 & 0.02 & 0.10 & 0.01 & 0.07 & 0.11 & 0.03 \\
\hline Financial difficulties 2011 & -0.01 & 0.02 & -0.01 & $0.07 *$ & 0.03 & 0.10 & -0.01 & 0.04 & -0.01 \\
\hline Living with both parents 2004 & 0.05 & 0.05 & 0.04 & -0.10 & 0.09 & -0.05 & 0.01 & 0.10 & 0.01 \\
\hline Steady relationship 2011 & 0.02 & 0.04 & 0.02 & 0.03 & 0.08 & 0.02 & 0.12 & 0.09 & 0.06 \\
\hline Parenthood 2011 & -0.10 & 0.10 & -0.05 & -0.30 & 0.20 & -0.09 & 0.07 & 0.18 & 0.02 \\
\hline Autonomous motivation 2011 & -0.01 & 0.00 & -0.07 & -0.01 & 0.01 & -0.06 & -0.01 & 0.01 & -0.06 \\
\hline Personality alpha 2008 & -0.10 & 0.05 & -0.09 & $-0.29 * *$ & 0.10 & -0.16 & 0.13 & 0.10 & 0.06 \\
\hline Personality beta 2008 & $0.19 * * *$ & 0.04 & 0.21 & $0.43 * * *$ & 0.08 & 0.28 & $0.28 * *$ & 0.08 & 0.16 \\
\hline$R^{2}$ & \multicolumn{3}{|c|}{$0.27 * * *$} & \multicolumn{3}{|c|}{$0.41 * * *$} & \multicolumn{3}{|c|}{$0.14 *$} \\
\hline
\end{tabular}

